\title{
Zero prevalence of hepatitis $B$ and hepatitis $C$ infections in clinicopathologically proven lichen planus cases: a cross sectional study at a tertiary care centre in South India
}

\author{
Lekshmi Sajini, Gopikrishnan Anjaneyan*, Soumya Jagadeesan, Vinitha Varghese Panicker, \\ Sreedevan V., Gopakumar, Jacob Thomas
}

Department of Dermatology, Amrita Institute of Medical Sciences, Amrita Vishwa Vidyapeetham, Kochi, Kerala, India

Received: 12 July 2017

Revised: 04 August 2017

Accepted: 05 August 2017

*Correspondence:

Dr. Gopikrishnan Anjaneyan,

E-mail: drgopikrishnana@gmail.com

Copyright: () the author(s), publisher and licensee Medip Academy. This is an open-access article distributed under the terms of the Creative Commons Attribution Non-Commercial License, which permits unrestricted non-commercial use, distribution, and reproduction in any medium, provided the original work is properly cited.

\begin{abstract}
Background: Lichen planus (LP) is a common chronic mucocutaneous inflammatory disorder of unknown etiology. Several editorials, chapters, studies have suggested an association between hepatitis $\mathrm{C}$ virus and hepatitis B virus (to a lesser extent) in LP. This association was not seen in various parts of the world including India.

Methods: Patients attending the dermatology outpatient department with lichen planus confirmed by histopathologic examination were included in the study and along with clinic-epidemiological data, all the patients were tested for hepatitis B and hepatitis $\mathrm{C}$ infection.

Results: A total of 84 patients of clinico-pathologically proven lichen planus were included in the study out of which 31 were males and 53 were females. The most common age group of lichen planus in our study group was 40-50 years. Major histopathological findings were basal cell degeneration (92.7\%), hyperkeratosis (89\%), pigment incontinence $(73 \%)$ and lymphohistiocytic infiltration $(70 \%)$. All patients in this study group tested negative for HBsAg and anti-HCV antibodies.

Conclusions: Although numerous studies around the world have suggested an association between HCV and HBV infections with lichen planus- multiple subsequent studies including the present study shows contrasting results especially in this part of the world. The authors believe routine screening of lichen planus patients for presence of hepatitis B and hepatitis C infection is not warranted, particularly in Indian population.
\end{abstract}

Keywords: Lichen planus, Hepatitis C, Hepatitis B, Histopathology

\section{INTRODUCTION}

Lichen planus (LP), which was first described by Jonathan Hutchinson in 1869, is a common chronic mucocutaneous inflammatory disorder of unknown etiology. It has characteristic clinical and pathological features affecting the skin, mucus membrane, nails, and hair. LP can present in many forms like actinic, annular, atrophic, erosive, follicular (lichen planopilaris), guttate, hypertrophic, linear, papular and vesiculobullous. Skin lesions are typically characterized by a white lace-like pattern (Wickham's striae) on papules, which is pathognomonic. Lesions may be confined to the mouth, or with minimal accompanying skin involvement, accounting for almost $15 \%$ of all cases. ${ }^{1}$ A clinically suspected case of LP may be confirmed histologically by a simple skin biopsy. 
Several studies have suggested a major role for hepatitis $\mathrm{C}$ virus and hepatitis $\mathrm{B}$ virus (to a lesser extent) in the pathogenesis of LP. $^{2-6}$ Many reports have shown contrasting results to this which has been attributed to various factors ranging from genetics to regional differences. $^{7-10}$ Another reason for these contrasting results is that many have included clinically diagnosed cases of lichen planus without histological confirmation which may lead to erroneous results as we know many lichenoid disorders can mimic lichen planus. Lichen planus is still quoted when chapters are written about the possible association with Hepatitis B and C virus. ${ }^{1,11,12}$

Few studies have been done in India to study this association and the guidelines regarding the testing of hepatitis B and C in all cases of LP are not available. ${ }^{9,10,13}$ This study was undertaken to determine the prevalence of hepatitis B and hepatitis C infections in histologically proven lichen planus cases in this part of the world and to understand whether testing for hepatitis B and C in cases of LP may benefit the patient.

\section{METHODS}

Eighty four consecutive consenting patients attending the dermatology outpatient department (at Amrita Institute of Medical Sciences, Kochi) with lichen planus confirmed by histopathologic examination were included in the study.

This cross-sectional study was done at a tertiary care centre from May 2013-June 2014 after obtaining permission from the institutional ethics committee. Patients clinically diagnosed with lichen planus and confirmed by histopathologic examination were included in the study. Patients who were not willing for hepatitis B and hepatitis $\mathrm{C}$ serology testing were excluded from the study. Detailed history including medications, dental impants, stress, vaccination for hepatitis B and C any other comorbidities, personal and family history were noted in the specifically designed proforma.

General examination and detailed dermatological examination was done in all patients and documented in the proforma. Hepatitis B (HBsAg) and hepatitis C (antiHCV) testing was done using ARCHITECT® kits. The ARCHITECT® HBsAg qualitative assay is a chemiluminescent microparticle immunoassay (CMIA) for the qualitative detection of hepatitis B surface antigen (HBsAg) in human serum and plasma. The ARCHITECT ${ }^{\circledR}$ Anti-HCV assay is a chemiluminescent microparticle immunoassay (CMIA) for the qualitative detection of antibody to hepatitis $\mathrm{C}$ virus (anti-HCV) in human serum and plasma.

The data were entered in Microsoft excel and analysed using descriptive statistical tools including numerical frequencies, proportions and percentages.

\section{RESULTS}

A total of 84 patients of clinico-pathologically proven lichen planus were included in the study out of which 31 were males and 53 were females. The most common age group of lichen planus in our study group was 40-50 years (Table 1). A total of 56 patients had skin involvement, 15 patients had only oral lesions, whereas 13 patients had both oral and cutaneous involvement. Most common presenting symptoms were itching and hyperpigmentation in cutaneous lichen planus and burning sensation in oral lichen planus. In our study group, the most common type was classical lichen planus in skin and reticulate type in oral lichen planus (Table 2).

Table 1: Age and sex distribution.

\begin{tabular}{|c|c|c|c|}
\hline \multirow{2}{*}{ Age (in years) } & \multicolumn{2}{|c|}{ Sex } & \multirow{2}{*}{ Total } \\
\hline & Male & Female & \\
\hline Below 10 & 0 & 1 & 1 \\
\hline $11-20$ & 7 & 4 & 11 \\
\hline 21-30 & 3 & 4 & 7 \\
\hline $31-40$ & 6 & 6 & 12 \\
\hline 41-50 & 3 & 16 & 19 \\
\hline $51-60$ & 5 & 12 & 17 \\
\hline Above 61 & 7 & 10 & 17 \\
\hline Total & 31 & 53 & 84 \\
\hline
\end{tabular}

Table 2: Types of lichen planus.

\begin{tabular}{|ll|}
\hline Clinical type & Number (\%) \\
\hline Classical lichen planus & $41(48.8)$ \\
\hline Oral lichen planus & $15(17.9)$ \\
\hline Hypertrophic lichen planus & $4(4.8)$ \\
\hline Follicular lichen planus & $1(1.2)$ \\
\hline Lichen planus pigmentosus & $8(9.5)$ \\
\hline Bullous lichen planus & $2(2.4)$ \\
\hline $\begin{array}{l}\text { Classical lichen planus and oral } \\
\text { lichen planus }\end{array}$ & $13(15.5)$ \\
\hline
\end{tabular}

Table 3: Associated diseases.

\begin{tabular}{|ll|}
\hline Associated diseases & Number $(\%)$ \\
\hline Diabetes & $13(15.5)$ \\
\hline Thyroid disorders & $11(13.1)$ \\
\hline Jaundice & $5(5.9)$ \\
\hline Candidiasis & $5(5.9)$ \\
\hline Atopy & $6(7.1)$ \\
\hline Rheumatoid arthritis & $1(1.2)$ \\
\hline No associated disease & $41(48.8)$ \\
\hline
\end{tabular}

Koebners phenomenon was seen in $23.1 \%$ cases. Most common comorbidity was diabetes mellitus followed by thyroid disorders (Table 3). Major histopathological findings among the study group were basal cell degeneration $(92.7 \%)$, hyperkeratosis $(89 \%)$, pigment incontinence $(73 \%)$ and lymphohistiocytic infiltration $(70 \%)$. 
All patients in this study group tested negative for HBsAg and anti-HCV antibodies.

\section{DISCUSSION}

Lichen planus is an idiopathic inflammatory papulosquamous disease of the skin, nail and mucosal membranes, often associated with periods of relapses and remissions. Its prevalence is approximately $0.5 \%$ of the population. $^{1}$

Hepatitis B and C are viral infections that affect the liver, may result in chronic disease and may sometimes be associated with autoimmune disorders. As both hepatitis $\mathrm{B}$ and $\mathrm{C}$ are associated with an aberrant immune response, it is possible that both viruses may independently trigger or exacerbate lichen planus. ${ }^{2}$ The first report showing an association between LP and HCV infection was published by Rebora et al in $1978 .{ }^{14}$ The role played by $\mathrm{HCV}$ in triggering $\mathrm{LP}$ remains unclear. Several studies have suggested a role for hepatitis $C$ virus in LP, particularly in Japanese and Mediterranean populations but this finding has not been consistent in subsequent studies. ${ }^{1}$

Various studies, editorials and meta-analyses have demonstrated a significant association between lichen planus and infection with hepatitis $\mathrm{C}$ virus (HCV). Several meta-analysis reports have demonstrated a strong link between oral LP and HCV infection, showing that OLP patients have six fold higher risk for HCV infection and also that oral LP patients have a higher risk than controls of being HCV seropositive. ${ }^{3,15}$ They reported lichen planus to be 2.5 to 4.5 times more likely to develop in the HCV-seropositive patients than in normal population. ${ }^{16,17}$ No concrete association between LP and HCV was detected in India. ${ }^{8,9,13,18}$ Hepatitis B virus (HBV) has also been shown to have a causal association in LP cases. ${ }^{1,19,20}$ Other viruses which have been implicated in the pathogenesis of LP include human herpesvirus-6 and human herpesvirus-7 and varicella zoster virus. ${ }^{21,22}$ Hepatitis $B$ vaccines have also been shown to trigger LP in some patients. ${ }^{1,23,24}$ The exacerbation of lichen planus by interferon alpha which is used for the treatment of hepatitis has been previously reported. $^{25}$

Genetic, environmental, geographical factors, vaccines and treatment modalities have been suggested as a reason for this association. Systemic inflammation plays an important role in both lichen planus and hepatitis and hence there could be a possible pathomechanism relating them. Lichen planus is significantly associated with hepatitis $\mathrm{C}$ infection in some regions like Southeast Asia, South America, the Middle East and Southern Europe, but not in other regions like North America, Northern Europe and Africa. These differences may be related to genetic factors. ${ }^{2,17,26}$

A meta-analysis by Lodi et al concluded that there was marked study and geographical variability, with the relationship between $\mathrm{HCV}$ and LP being prevalent in Japan, Mediterranean countries and the USA and less in other parts of the world. There was a strong geographical association too as coexistence of LP and HCV infection was observed mainly in Southern Europe where HCV is highly prevalent. Some of the studies with debatable epidemiological data have been attributed to methodological biases (such as misclassification of the disease, small sample size, and recent acquisition of $\mathrm{HCV}$, etc.) and further to a broad geographic effect linked to worldwide difference in prevalence of $\mathrm{HCV}^{3,26}$

$\mathrm{HCV}$ infection has an indolent course patients may present only in late stages of the disease with cirrhosis and other serious complications. The association is important as it needs to be seen whether screening of patients with LP may help in early detection of the HCV infection in this subset of patients. Early diagnosis, treatment and education of these patients may decrease risk of complications as well as prevent transmission to others. In a cost-effectiveness analysis, screening serological test of patients with LP was found costeffective only with the presence of other risk factors. ${ }^{27}$

All the patients of lichen planus in this study tested negative for hepatitis $B$ and hepatitis $C$ virus. Most of the studies which have measured the association between lichen planus and hepatitis B \& $\mathrm{C}$ have a major limitation, which is a lack of validation of the diagnosis of lichen planus. Lichenoid drug reactions (or other causes of lichenoid eruptions) are often misdiagnosed and if they are included in the study samples of LP, then it would result in an overestimation of the association of LP with HCV and HBV. A histopathological confirmation of the clinical diagnosis is the gold standard in lichen planus diagnosis and hence by doing so in our study we have overcome this limitation making the results more reliable. However, larger, multicentric and long term follow up studies are required to further corroborate these results. Although numerous studies around the world have suggested an association between $\mathrm{HCV}$ and $\mathrm{HBV}$ infections with lichen planus- multiple subsequent studies including the present study shows contrasting results especially in this part of the world.

The authors believe routine screening of lichen planus patients for presence of hepatitis $B$ and hepatitis C infection is not warranted particularly in Indian population.

\section{ACKNOWLEDGEMENTS}

We would like to thank Dr. Malini Eapen, Professor in pathology department and the patients involved with this study for their contribution.

\author{
Funding: No funding sources \\ Conflict of interest: None declared \\ Ethical approval: The study was approved by the \\ institutional ethics committee
}




\section{REFERENCES}

1. Piguet V, Breathnach S M, Le Cleach L. Lichen Planus and Lichenoid Disorders. In: Griffiths C, Barker J, Bleiker T, Chalmers R, Creamer D, editors. Rook's text book of dermatology. 9th ed. Wiley-Blackwell; 2016;37:1-28.

2. Birkenfeld S, Dreiher J, Weitzman D, Cohen AD. A study on the association with hepatitis B and hepatitis $\mathrm{C}$ in 1557 patients with lichen planus. J Eur Acad Dermatol Venereol. 2011;25(4):436-40.

3. Lodi G, Pellicano R, Carrozzo M. Hepatitis C virus infection and lichen planus: a systematic review with meta-analysis. Oral Dis. 2010;16:601-12.

4. Cribier B, Garnier C, Laustriat D, Heid E. Lichen planus and hepatitis $\mathrm{C}$ virus infection: an epidemiologic study. J Am Acad Dermatol. 1994;31(6):1070-2.

5. Imhof M, Popal H, Lee J, -H, Zeuzem S, Milbradt $\mathrm{R}$, Prevalence of Hepatitis C Virus Antibodies and Evaluation of Hepatitis C Virus Genotypes in Patients with Lichen planus. Dermatology. 1997;195:1-5.

6. Nagao Y, Sata M, Tanijsawa K, Itoh K, Kameyama, $\mathrm{T}$. Lichen planus and hepatitis $\mathrm{C}$ virus in the Northern Kyushu region of Japan. Euro J Clin Investigat. 1995;25:910-4.

7. Rajouria EA, Amatya A, Karn D. Association of Lichen Planus with HCV and HBV in Nepal. Postgraduate Med J NAMS. 2011;11:1-4.

8. Rübsam K, Schroll A, Weisenseel P, Multhaup S, Ruzicka T, Prinz JC. Lichen planus and hepatitis virus infections: causal association? J Dtsch Dermatol Ges. 2011;9(6):464-8.

9. Jayavelu P, Sambandan T. Prevalence of hepatitis C and hepatitis B virus infection(s) in patients with oral lichen planus. J Pharm Bioall Sci. 2012;4(2):397-405.

10. Das A, Das J, Majumdar G, Bhattacharya N, Neogi DK, Saha B. No association between seropositivity for Hepatitis $\mathrm{C}$ virus and lichen planus: A case control study. Indian J Dermatol Venereol Leprol 2006;72:198-200.

11. Daoud MS, Pittelkow MR. Lichen Planus. In: Goldsmith LA, Katz SI, Gilchrest BA, Paller AS, Leffell DJ, Wolff K, eds. Fitzpatrick's Dermatology in General Medicine. 3rd ed. Mc Graw Hill; 2012: 297.

12. Shiohara T, Kano Y. Lichen Planus and Lichenoid Dermatoses. In Bolognia JL, Jorizzo JL, Schaffer JV edi. Dermatology. 3rd ed. Elsevier Saunders; 2012: 184.

13. Kumar KPM, Jois HS, Hallikerimath S, Kale AD. Oral Lichen Planus as an Extra-hepatic Manifestation of Viral Hepatitis-Evaluation in Indian Subpopulation. J Clin Diagnos Res. JCDR. 2013;7(9):2068-9.

14. Rebora A, Patri P, Rampini E, Crovato F, Ciravegna G, Rebora A, et al. Erosive lichen planus and cirrhotic hepatitis. Ital Gen Rev Dermatol. 1978;15:123-31.

15. Petti S, Rabiei M, De Luca M, Scully C. The magnitude of the association between hepatitis $\mathrm{C}$ virus infection and oral lichen planus: meta-analysis and case control study. Odontology. 2011;99:16878.

16. Le Cleach L, Chosidow O. Clinical practice. Lichen planus. N Engl J Med. 2012;366:723-32

17. Shengyuan L, Songpo Y, Wen W, Wenjing T, Haitao Z, Binyou W. Hepatitis C virus and lichen planus: a reciprocal association determined by a meta-analysis. Arch Dermatol. 2009;145:1040-7.

18. Narayan S, Sharma RC, Sinha BK, Khanna V. Relationship between lichen planus and hepatitis $C$ virus. Indian J Dermatol Venereol Leprol. 1998;64:281-2

19. Daramola OO, George AO, Ogunbiyi AO, Otegbayo JA. Hepatitis B virus in Nigerians with lichen planus. West Afr J Med. 2004;23(2):104-6.

20. Rubsam K, Schroll A, Weisenseel P, Multhaup S, Ruzicka T, Prinz JC. Lichen planus and hepatitis virus infections: causal association? J Deut Dermatol Gesellschaft. 2011;9(6):464-8.

21. De Vries HJ, van Marle J, Teunissen MB, Picavet $\mathrm{D}$, Zorgdrager $\mathrm{F}$, Bos JD, et al. Lichen planus is associated with human herpes virus type 7 replication and infiltration of plasmacytoid dendritic cells. Br J Dermatol. 2006;154(2):361-4.

22. Mizukawa Y, Horie C, Yamazaki Y, Shiohara T. Detection of varicella-zoster virus antigens in lesional skin of zosteriform lichen planus but not in that of linear lichen planus. Dermatology. 2012;225(1):22-6.

23. Rebora A, Rongioletti F, Drago F, Parodi. Lichen planus as a side effect of $\mathrm{HBV}$ vaccination. Dermatology. 1999;198(1):1-2.

24. Limas C, Limas CJ. Lichen planus in children: a possible complication of hepatitis $\mathrm{B}$ vaccines. Pediatr Dermatol. 2002;19(3):204-9.

25. Grossmann SM, Teixeira R, de Aguiar MC, do Carmo MA. Exacerbation of oral lichen planus lesions during treatment of chronic hepatitis $\mathrm{C}$ with pegylated interferon and ribavirin. Eur $\mathbf{J}$ Gastroenterol Hepatol. 2008;20:702-6.

26. Lodi G, Giuliani M, Majorana A, Sardella A, Bez C, Demarosi F, et al. Lichen planus and hepatitis $\mathrm{C}$ virus: a multicentre study of patients with oral lesions and a systematic review. $\mathrm{Br} \mathrm{J}$ Derm. 2004;151:1172-81.

27. Mahboobi N, Agha-Hosseini F, Lankarani KB. Hepatitis C Virus and Lichen Planus: The Real Association. Hepatitis Monthly. 2010;10(3):161-4.

Cite this article as: Sajini L, Anjaneyan G, Jagadeesan S, Panicker VV, Sreedevan V, Gopakumar, et al. Zero prevalence of hepatitis B and hepatitis $\mathrm{C}$ infections in clinicopathologically proven lichen planus cases: a cross sectional study at a tertiary care centre in South India. Int J Res Dermatol 2017;3:351-4. 